\title{
Disseminated coccidioidomycosis-related cervical intramedullary lesion causing quadriplegia in an immunocompetent host
}

\author{
James Michael Noto, ${ }^{1}$ Raquel Nahra, ${ }^{2}$ Tapan Kavi ${ }^{3}$
}

'Department of Neurology, Cooper University Hospital, Camden, New Jersey, USA ${ }^{2}$ Department of Medicine, Cooper University Hospital, Camden, New Jersey, USA ${ }^{3}$ Department of Neurology and Neurosurgery, Cooper University Hospital, Camden, New Jersey, USA

\section{Correspondence to}

Dr James Michael Noto,

noto-james@cooperhealth.edu

Accepted 28 November 2017

\section{DESCRIPTION}

A 41-year-old man with a history of crystal methamphetamine and alcohol abuse had progressive fever, nausea, headache, gait difficulties and seizures over 4 weeks while living in California and Mexico. He was diagnosed with meningitis, treated with antibacterials and discharged to a rehabilitation facility. One month later, he had recurrent symptoms with weakness of both arms and legs. Neuroimaging revealed

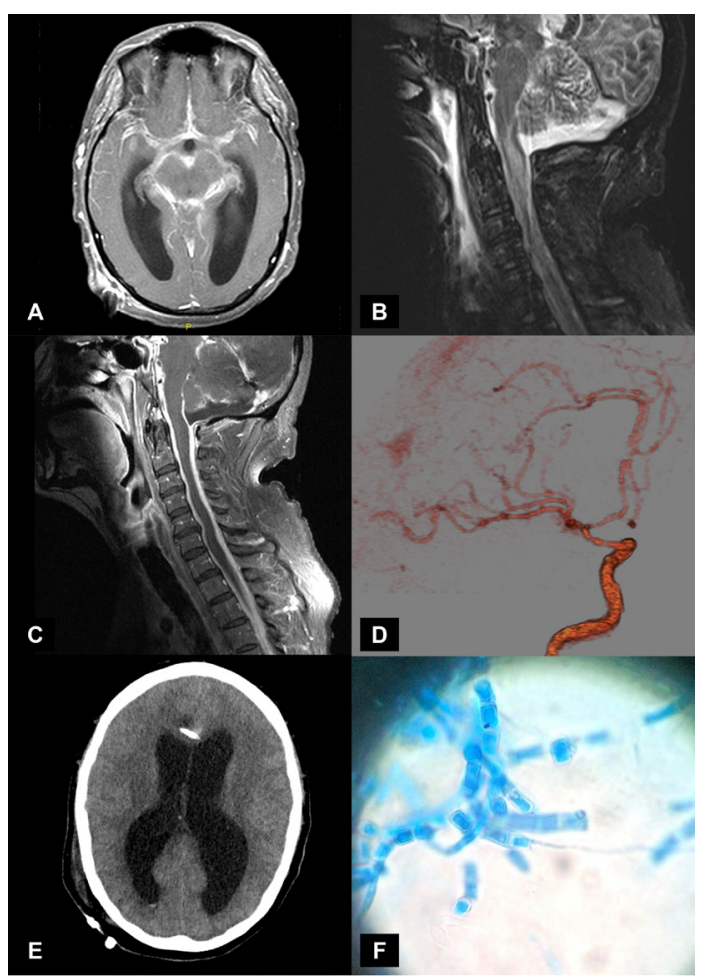

Figure 1 (A) MRI of brain with gadolinium, axial view showing enhancement consistent with extensive basilar pachymeningitis, and leptomeningitis. Also seen is hydrocephalus. (B) MRI of cervical spine, T2 -weighted short-tau inversion recovery sequence, sagittal view, with a central intramedullary lesion spanning from $\mathrm{C} 1$ through C6 of the cervical spinal cord. (C) MRI of cervical spine, T1 sagittal view with gadolinium shows extensive epidural enhancement. No enhancement of the intramedullary lesion is seen. (D) MRA of head, a reconstruction of the left anterior circulation shows a beading pattern consistent with arteritis. (E) CT of head without contrast, an axial view showing worsening hydrocephalus. (F) Cerebrospinal fluid culture showing thin, hyaline, septate hyphae and barrel-shaped arthroconidia (lactophenol cotton blue stain) consistent with coccidioides. extensive basilar pachymeningitis, leptomeningitis, hydrocephalus (figure 1A), cervical epidural enhancement (figure 1B) and a non-enhancing central cervical intramedullary lesion spanning C1 through C6 (figure 1C). He was started on fluconazole $800 \mathrm{mg}$ daily due to his travel history, although a serum antibody test was negative by double immunodiffusion $(<1: 1)$. A ventriculoperitoneal shunt was placed for hydrocephalus and he was discharged but remained quadriplegic. Two weeks later, he developed confusion and was found to have bilateral subcortical strokes on MRI with evidence of arteritis on MR angiogram (figure 1D). He was then transferred to our hospital and amphotericin was added. Testing for HIV, tuberculosis and immunosuppression was negative. He developed worsening hydrocephalus (figure 1E) and died after interventions were withdrawn. Cerebrospinal fluid culture (figure $1 \mathrm{~F}$ ) and coccidioides IgG antibody by ELISA of $3.1 \mathrm{ng} / \mathrm{mL}$ later confirmed the diagnosis of coccidioidomycosis

We present a case of an intramedullary spinal cord lesion with quadriplegia from coccidioides infection in an immunocompetent host. Disseminated coccidioidomycosis is seen in only $1 \%-5 \%$ of infected patients. ${ }^{12}$ Recognising the complication of spinal cord intramedullary involvement is important as delayed diagnosis and treatment can lead to poor outcomes. ${ }^{3}$

\section{Learning points}

Even in an immunocompetent host, intramedullary spinal cord involvement can be a manifestation of disseminated coccidioidomycosis and accompany the more recognisable presentation of coccidioidal meningitis.

- Delays in the diagnosis and treatment of coccidioidal meningitis are not uncommon but as seen in this case can lead to further neurological complications such as hydrocephalus and spinal cord involvement.

Contributors JMN and TK contributed to the conception, design, drafting and revisions of the article; acquisition, analysis and interpretation of the data; final approval of the article and the agreement to be accountable for the accuracy and integrity of its content. RN contributed to the critical revisions to the article acquisition, analysis and interpretation of the data; final approval of the article and the agreement to be accountable for the accuracy and integrity of its content.

Competing interests None declared.

Patient consent Obtained. 
Provenance and peer review Not commissioned; externally peer reviewed.

(c) BMJ Publishing Group Ltd (unless otherwise stated in the text of the article) 2017. All rights reserved. No commercial use is permitted unless otherwise expressly granted.

\section{REFERENCES}

1 Tan LA, Kasliwal MK, Nag S, et al. Rapidly progressive quadriparesis heralding disseminated coccidioidomycosis in an immunocompetent patient. J Clin Neurosci 2014;21:1049-51

2 Bajema KL, Dalesandro MF, Fredricks DN, et al. Disseminated coccidioidomycosis presenting with intramedullary spinal cord abscesses: Management challenges. Med Mycol Case Rep 2017;15:1-4.

3 Lammering JC, Iv M, Gupta N, et al. Imaging spectrum of CNS coccidioidomycosis: prevalence and significance of concurrent brain and spinal disease. AJR Am J Roentgenol 2013;200:1334-46.

Copyright 2017 BMJ Publishing Group. All rights reserved. For permission to reuse any of this content visit

http://group.bmj.com/group/rights-licensing/permissions.

BMJ Case Report Fellows may re-use this article for personal use and teaching without any further permission.

Become a Fellow of BMJ Case Reports today and you can:

- Submit as many cases as you like

- Enjoy fast sympathetic peer review and rapid publication of accepted articles

Access all the published articles

Re-use any of the published material for personal use and teaching without further permission

For information on Institutional Fellowships contact consortiasales@bmjgroup.com

Visit casereports.bmj.com for more articles like this and to become a Fellow 